\title{
Biometrics of Razorbills Alca torda staying during the non- breeding season in the Polish Baltic zone
}

\author{
Biometri hos tordmular Alca torda som utanför häckningssäsongen vistas $i$ den \\ polska zonen av Östersjön
}

WŁODZIMIERZ MEISSNER, JOANNA DROZDOWSKA \& SZYMON BZOMA

\begin{abstract}
Biometrical analysis of Razorbills Alca torda captured or drowned in fishing nets in the Polish economic zone of the Baltic Sea is based on measurements of 98 individuals collected in the non-breeding period (October-April) in 2006-2013. These birds are assumed to represent the breeding population of the Baltic Sea as recoveries show that very few other birds visit that area. Bill depth and wing length of juveniles were much smaller than in older birds which suggests that the final size of these measurements is not achieved during the first winter but continue to increase as the birds grow older. In older birds only total head length and bill length were significantly larger in males than in females. Mean bill depth of Razorbills from the Polish Baltic zone fits well to clinal variation

from south-west to north of the European part of the breeding range. However, mean wing length was much larger than expected according to the regression, which might result from differences in measuring technique. On the other hand it cannot be excluded that the Baltic population may actually have longer wings.

Włodzimierz Meissner and Joanna Drozdowska, Avian Ecophysiology Unit, Department of Vertebrate Ecology \& Zoology, University of Gdańsk, Wita Stwosza 59, 80308 Gdańsk, Poland. E-mail: w.meissner@ug.edu.pl Szymon Bzoma, Waterbird Research Group KULING, Świerkowa 34/7, 81-526 Gdynia, Poland.
\end{abstract}

Received 14 August 2013, Accepted 1 October 2013, Editor S. Svensson

\section{Introduction}

Remarkable variability in biometrics among Razorbills Alca torda has attracted attention of ornithologists at least since the 1940 s resulting in several publications on geographical (e.g. Salomonsen 1944, Jones 1990, Barrett et al. 1997) and sexual differences in linear measurements (e.g. Anker-Nilssen et al. 1988, Jones 1988, Wagner 1999, Grecian et al. 2003). Breeding populations of Razorbills in Europe are divided into two groups. One group of smaller birds, referred to subspecies Alca torda islandica inhabits Iceland, the Faroes, Ireland, Great Britain and France, while the second, composed of larger birds representing Alca torda torda, breeds in Scandinavia and Russia (Glutz von Blotzheim \& Bauer 1982). The proportion of larger and smaller individuals was often used in assessing the origin of oiled birds collected after ship accidents (Jones et al. 1985, Anker-Nilssen et al. 1988, Camphuysen \& Leopold 2004, Heubeck et al. 2011).

Clinal increase in size of Razorbills from the south-western towards north-eastern part of the breeding range is observed in Europe, with the exception of Baltic birds which appear to be much larger than would be expected from their geographical position (Barrett et al. 1997). However, information on biometrics of Razorbills recorded in the Baltic Sea is scarce. Published data used in Barrett's et al. (1997) paper come from breeding colonies in the islands of Graesholm, Denmark (Jones 1990, N=30) and Stora Karlsö, Sweden (Salomonsen 1944, N=17). Moreover, at least partly these data were taken from museum specimens and were corrected by adding a constant value of $2 \mathrm{~mm}$ to wing length and $1 \mathrm{~mm}$ to bill depth (Barrett et al. 1997).

This study is aimed at biometrical analysis of Razorbills captured or drowned in fishing nets in the Polish economic zone of the Baltic Sea in the non-breeding period with special emphasis on checking if Baltic birds fit to the clinal variation of size of European Razorbills presented by Barrett et al. (1997).

\section{Methods}

This study is based on measurements of 98 Razorbills collected from October to April in 2006-2013. Seventy five birds were taken from fishing nets in 
the open sea of the Polish Exclusive zone of the Baltic. Among them 27 were alive and were ringed and released. The dead birds were collected from fishing harbours situated in the Gulf of Gdańsk, where boats are operating near the coast.

Total head length (Green 1980), bill length from the end of feathering on the upper mandible to the tip, bill depth at gonys and tarsus length (Hanners \& Patton 1985) were measured using dial callipers with an accuracy of $0.1 \mathrm{~mm}$. Measurements of wing length (maximal straightened chord, Evans 1986) and tarsus with middle toe included (Piersma 1984) were taken with a stopped ruler with an accuracy of $1 \mathrm{~mm}$. Birds were weighed to the nearest $1 \mathrm{~g}$ (dead birds after drying). Most of dead individuals were sexed by gonadal inspection. Ageing of birds was performed according to bill ornament. However taking into account the controversy over development of the number of bill groves with age (de Wijs 1985, Jones 1988), the birds were divided into two age groups: juveniles with no white vertical line and no grooves on the bill and older birds (including immatures and adults - here called adults) with white line only and white line with at least one groove. Due to small sample size juveniles were excluded from the majority of analyses. Not all measurements were taken from each indi- vidual, therefore the sample sizes differed in specific measurements.

Data on mean wing length and bill depth of Razorbills from different breeding colonies were obtained from published sources, while data taken from museum specimens were excluded (Barrett et al. 1997, Jones 1990, Wagner 1999). When data on males and females were presented separately (Wagner 1999) or there were two sets of measured birds from one breeding colony (Barett et al. 1997 and Jones 1990 for Hornøya), mean measurements for birds were calculated as weighted average. Only mean wing length and mean bill depth calculated from sample size equal to or greater than 30 were taken into account.

To check if Baltic birds fit to the geographical cline in body size described by Barrett et al. (1997) mean wing lengths and bill depths were correlated with an index of the geographical position of each breeding colony calculated as a sum of latitude and longitude as in the Barrett et al. (1997) paper. Geographical position of fishing harbours, where dead birds were collected, and the position of the ship in case of birds captured alive, were averaged and taken as the assumed position of all individuals from the Polish zone of the Baltic.

Table 1. Mean measurements (M) of Razorbills drowned or captured alive in fishing nets in the Polish exclusive zone of the Baltic. Standard deviation (SD) and sample size (N) are given. Coefficient of variation (V) concerns older unsexed birds.

Mått hos tordmularna som drunknat eller fångats levande i fisknät inom den polska ekonomiska zonen i Östersjön. Efter medelvärdet (M) anges standarddeviation (SD)och antal $(N)$ fåglar. Variationskoefficienten (V) avser äldre fåglar av båda könen.

\begin{tabular}{|c|c|c|c|c|c|c|c|c|}
\hline Age/sex & & $\begin{array}{c}\text { Total } \\
\text { head } \\
\text { Huvud } \\
\text { totalt } \\
{[\mathrm{mm}]}\end{array}$ & $\begin{array}{c}\text { Bill } \\
\text { depth } \\
\text { Näbb- } \\
\text { höjd } \\
{[\mathrm{mm}]}\end{array}$ & $\begin{array}{l}\text { Bill } \\
\text { length } \\
\text { Näbb- } \\
\text { längd } \\
{[\mathrm{mm}]}\end{array}$ & $\begin{array}{l}\text { Wing } \\
\text { length } \\
\text { Ving- } \\
\text { längd } \\
{[\mathrm{mm}]}\end{array}$ & $\begin{array}{c}\text { Tarsus } \\
\text { plus toe } \\
\text { Tars } \\
\text { plus tå } \\
\text { [mm] }\end{array}$ & $\begin{array}{c}\text { Tarsus } \\
\text { Tars } \\
{[\mathrm{mm}]}\end{array}$ & $\begin{array}{c}\text { Body } \\
\text { mass } \\
\text { Kropps- } \\
\text { massa } \\
{[\mathrm{g}]}\end{array}$ \\
\hline Juveniles & $\begin{array}{l}\text { M } \\
\text { SD } \\
\text { N }\end{array}$ & $\begin{array}{c}96.19 \\
\pm 2.39 \\
11\end{array}$ & $\begin{array}{c}17.43 \\
\pm 0.95 \\
8\end{array}$ & $\begin{array}{c}33.83 \\
\pm 1.17 \\
9\end{array}$ & $\begin{array}{c}206.4 \\
\pm 4.29 \\
14\end{array}$ & $\begin{array}{c}87.4 \\
\pm 3.20 \\
14\end{array}$ & $\begin{array}{c}35.05 \\
\pm 1.50 \\
4\end{array}$ & $\begin{array}{c}909.9 \\
\pm 60.65 \\
8\end{array}$ \\
\hline $\begin{array}{l}\text { Older } \\
\text { Males }\end{array}$ & $\begin{array}{c}\mathrm{M} \\
\mathrm{SD} \\
\mathrm{N} \\
\end{array}$ & $\begin{array}{c}97.57 \\
\pm 1.80 \\
29 \\
\end{array}$ & $\begin{array}{c}22.12 \\
\pm 1.25 \\
30 \\
\end{array}$ & $\begin{array}{c}35.04 \\
\pm 1.14 \\
29 \\
\end{array}$ & $\begin{array}{c}213.2 \\
\pm 3.86 \\
30 \\
\end{array}$ & $\begin{array}{c}88.9 \\
\pm 3.10 \\
30 \\
\end{array}$ & $\begin{array}{c}35.54 \\
\pm 1.57 \\
20 \\
\end{array}$ & $\begin{array}{c}894.4 \\
\pm 104.51 \\
29\end{array}$ \\
\hline $\begin{array}{l}\text { Older } \\
\text { females }\end{array}$ & $\begin{array}{c}\mathrm{M} \\
\mathrm{SD} \\
\mathrm{N}\end{array}$ & $\begin{array}{c}95.08 \\
\pm 1.96 \\
27 \\
\end{array}$ & $\begin{array}{c}21.86 \\
\pm 1.11 \\
27\end{array}$ & $\begin{array}{c}34.18 \\
\pm 1.14 \\
23 \\
\end{array}$ & $\begin{array}{c}213.0 \\
\pm 5.15 \\
27\end{array}$ & $\begin{array}{c}88.1 \\
\pm 2.21 \\
27 \\
\end{array}$ & $\begin{array}{c}35.65 \\
\pm 1.16 \\
17\end{array}$ & $\begin{array}{c}890.3 \\
\pm 78.38 \\
26\end{array}$ \\
\hline $\begin{array}{l}\text { Older } \\
\text { birds } \\
\text { unsexed }\end{array}$ & $\begin{array}{l}\text { M } \\
\text { SD } \\
\text { N }\end{array}$ & $\begin{array}{c}96.19 \\
\pm 2.50 \\
77\end{array}$ & $\begin{array}{c}22.05 \\
\pm 1.24 \\
73\end{array}$ & $\begin{array}{c}34.37 \\
\pm 1.64 \\
62\end{array}$ & $\begin{array}{c}213.3 \\
\pm 4.65 \\
79\end{array}$ & $\begin{array}{c}89.04 \\
\pm 3.39 \\
79\end{array}$ & $\begin{array}{c}35.54 \\
\pm 1.39 \\
38\end{array}$ & $\begin{array}{c}891.8 \\
\pm 91.55 \\
56\end{array}$ \\
\hline V\% & & 2.6 & 5.6 & 4.8 & 2.2 & 3.8 & 3.9 & 10.3 \\
\hline
\end{tabular}




\section{Results}

Bill depth and wing length of juveniles were much smaller than in older birds, while other mean measurements were well within the range of one standard deviation from mean values of older birds (Table 1). Only total head length and bill length were significantly greater in adult males than in adult females (t-test, $\mathrm{t}=4.97, \mathrm{p}<0.001$ and $\mathrm{t}=2.70, \mathrm{p}=0.009$ for total head and bill length, respectively). Other measurements did not differ between sexes (t-test, $p>0.41$ in all cases). Hence, data on wing length and bill depth of males and females analysed in this study were pooled for the next analysis, i.e. fitting of the data to the geographical cline in size of Razorbills. Bill depth showed the highest coefficient of variation among all linear measurements followed by bill length (Table 1).

There was a significant increase in mean wing length and bill depth north-eastwards (Figure 1). Wing length and bill depth increased by $0.29 \mathrm{~mm}$ and $0.05 \mathrm{~mm}$ per 1 degree of the geographical index, respectively. However the standard error of estimate was six times greater in case of wing length compared to bill depth (5.13 versus 0.85 ) (Figure 1). The sum of geographical coordinates explained $42 \%$ and $47 \%$ of the variation in wing length and bill depth, respectively. The point representing birds measured in the Polish Baltic zone was situated within $95 \%$ confidence limit close to the regression line only in case of bill depth. Mean wing length was much higher than expected according to the regression and is lying far from the confidence limit of the regression line (Figure 1).

\section{Discussion}

Most adult Razorbills from the Baltic breeding colonies stay year around in the Baltic Sea and only some immatures move to Skagerrak, Kattegat and the North Sea (Bønløkke et al. 2006, Fransson et al. 2008). There are only few reports of Norwegian or Russian birds wintering in the western Baltic (Glutz von Blotzheim \& Bauer 1982, Cramp 1985). Hence, it may be assumed that data analysed in this study concerned birds from the Baltic breeding population.

Conspicuous differences in bill depth and wing length between juvenile and older birds show that the final size of these parts of the body is not achieved during the first winter. This result is consistent with data on post-fledging development of body measurements in this species, especially in
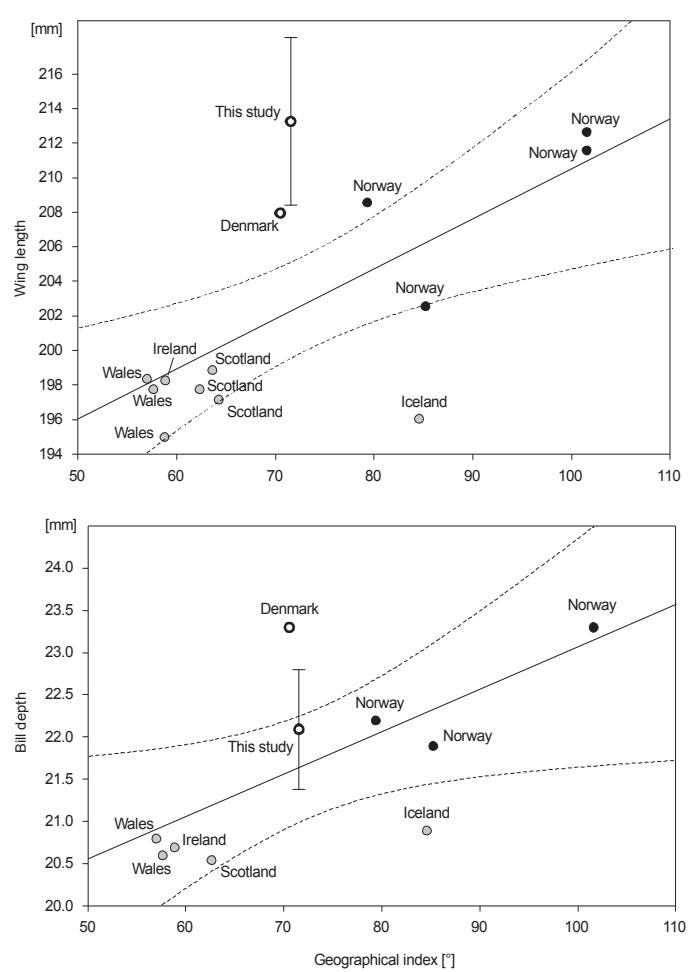

Figure 1. Wing length (top) and bill depth (bottom) of Razorbills in relation to the breeding colony localization or central position of the area, where birds were captured/collected for this study. Grey dots - subspecies A. t. islandica, black dots - subspecies A. t. torda, open dots - birds from the Baltic Sea. Geographical index was calculated as a sum of longitude and latitude. Vertical line - \pm standard deviation. The regression lines (solid line) and 95\% confidence limits (dashed lines) are shown.

Vingläng (övre) och näbbhöjd (nedre)hos tordmular i förhållande till ett geografiskt index för en koloni eller fångstområde (denna studie). Grå prickar rasen islandica, svarta prickar rasen torda, öppna prickar denna studie (vertikal linje visar en standardeviation). Det geografiska indexet är summan av latitud och longitud. Regressionslinjerna omges av 95-procentiga konfidensintervall.

case of bill depth which is still increasing up to the third winter of bird life (Jones 1988).

Biometrical differences between males and females are found only in bill and total head length. According to data from different breeding colonies Razorbill males are larger than females, but the differences are most pronounced in bill dimensions (Anker-Nilssen et al. 1988, Wagner 1999, Grecian et al. 2003), and this was confirmed also in this study. As it was impossible to reliably distinguish immatures and adults (de Wijs 1985, Jones 1988) birds from these two age classes were included into 
one category of older birds. This may have influenced mean values as well as increased the coefficient of variation, especially in case of bill depth, which slightly increases up to the third year of the Razorbill life (Jones 1988).

Mean bill depth of Razorbills from the Polish Baltic zone fits well to the clinal variation of this measurement from south-western to northern parts of the European breeding range. However, mean wing length is far above the regression line. This might be a result of the inter-observer differences in the wing measuring technique. It was declared in all studies that wing length was measured as maximum flattened chord (Barrett et al. 1989), but even slight differences in taking this measurement, like position of the point where the carpal joint is pressed, force of this pressure and the way of flattening the wing on the rule have crucial influence on this measurement when taken by different persons (Busse 2000, de Beer et al. 2011, authors' unpublished data). Probably this may be one of the reasons why mean wing length of Polish birds is so far away from the confidence limit of the regression line. However, it cannot be excluded that Baltic Razorbills indeed have longer wings than expected, especially as mean wing length of birds from Graesholm colony in Denmark is outside the confidence limit as well, and also mean bill depth of those birds is far above the regression line (Figure 1).

\section{Acknowledgements}

We are grateful to all colleagues for their assistance in the work on fishing boats. Special thanks to Sławka Fryderyk and Adam Janczyszyn for collecting birds from harbours. We also would like to thank Agnieszka Ożarowska for English correction of the manuscript.

\section{References}

Anker-Nilssen, T., Jones, P.H. \& Røstad, O.W. 1988. Age, sex and origins of auks (Alcidae) killed in the Skagerrak oiling incident of January 1981. Seabirds 11: 28-46.

Barrett, R.T., Anker-Nilssen, T. \& Krasnov, Y.V. 1997. Can Norwegian and Russian Razorbills Alca torda be identified by their measurements? Marine Ornithology 25: 5-8.

Bønløkke, J., Madsen, J.J., Thorup, K., Pedersen, K.T., Bjerrum, M. \& Rahbek, C. 2006. Dansk Trcekfuleatlas. Rhodos, Humlebæk.

Busse, P. 2000. Bird station manual. Gdańsk University Press, Gdańsk.

Camphuysen, C.J. \& Leopold, M.F. 2004. The Tricolor oil spill: characteristics of seabirds found oiled in The Netherlands. Atlantic Seabirds 6: 109-128.
Cramp, S. (ed.) 1985. Handbook of the birds of Europe, the Middle East and North Africa. Vol. 4. Oxford University Press, Oxford.

de Beer, S.J., Lockwood, G.M., Raijmakers , J.H.F.A., Scott, W.A., Oschadleus, H.D. \& Underhill, L.G. 2001. SAFRING bird ringing manual. Avian Demography Unit, Cape Town.

de Wijs, W.J.R. 1985. Reliability of ageing Razorbills. Seabird 8: 58.

Evans, P.R. 1986. Correct measurements of the wing length of waders. Wader Study Group Bull. 48: 11.

Fransson, T., Österblom, H. \& Hall-Karlsson, S. 2008. Svensk ringmärkningsatlas. Vol. 2. Naturhistoriska riksmuseet, Stockholm.

Grecian, V.D., Diamond, A.W. \& Chardine, J. W. 2003. Sexing Razorbills Alca torda breeding at Machias Seal Island, New Brunswick, Canada, using discriminant function analysis. Atlantic Seabirds 5: 73-80.

Green, G.H. 1980. Total head length. Wader Study Group Bull. 29: 18.

Glutz von Blotzheim, U. N. \& Bauer, K.M. 1982. Handbuch der Vögel Mitteleuropas. Vol. 8/II. Akademische Verlagsgesellschaft, Wiesbaden.

Hanners, L.A. \& Patton S.R. 1985. Sexing Laughing Gulls using external measurements and discriminant analysis. $J$. Field. Orn. 56: 158-164.

Heubeck, M., Aarvak, T., Isaksen, K., Johnsen, A., Petersen, I.K. \& Anker-Nilssen, T. 2011. Mass mortality of adult Razorbills Alca torda in the Skagerrak and North Sea area, autumn 2007. Seabirds 24: 11-32.

Jones, P.H., Barrett, C.F., Mudge, G.P. \& Harris, M.P. 1985. Examination of corpses of auks beached on East British coasts in February 1983. Seabird 8: 9-14.

Jones, P.H., Monnat, J.-Y. \&Harris, M.P. 1982. Origin, age and sex of auks (Alcidae) killed in the 'Amoco Cadiz' oiling incident in Brittany, March 1978. Seabird 6: 122-130.

Jones, P.H. 1988. Post-fledging wing and bill development in the Razorbill Alca torda islandica. Ring. \& Migr. 9: $11-17$.

Jones P.H. 1990. The occurrence of larger ('northern') Razorbills in British and Irish waters. Ringing \& Migration 11: 105-110.

Lyngs, P. \& Kampp, K. 1996. Ringing recoveries of Razorbills Alca torda and Guillemots Uria aalge in Danish waters. Dansk Ornitologisk Forenings Tidsskrift 90: 119-132.

Piersma, T. 1984. International wader migration studies along the East Atlantic Flyway during spring 1985. Final announcement of a Wader Study Group project. Wader Study Group Bull. 42: 5-9.

Salomonsen, F. 1944. The Atlantic Alcidae. The seasonal and geographical variation of the auks inhabiting the Atlantic Ocean and adjacent waters. Göteborgs Kung. Vetenskaps och Vitterhetssamhälles Handl. Följen 6, Ser. B, 3: 1-138.

Wagner, R.H. 1999. Sexual size dimorphism and assortative mating in Razorbills (Alca torda). Auk 116: 542-544. 


\section{Sammanfattning}

Tordmulens mått varierar från område till område. Två grupper brukar urskiljas i Europa. En grupp består av relativt små fåglar och bebor Island, Färöarna, Irland, Storbritannien och Frankrike. De brukar hänföras till en egen ras islandica. Fåglarna i Skandinavien och Ryssland är större och utgör rasen torda. Rasen islandica ökar i storlek från söder mot norr, men det har varit oklart vilken position Östersjön tordmular intar i trenden, främst på grund av ringa underlag. Eftersom Östersjön sällan besöks av andra tordmular är det nästan säkert att de fåglar vi mätt kommer från Östersjöns häckande bestånd. Däremot går det inte att bestämma till vilka häckningskolonier de hör.

Studien baserar sig på 98 tordmular som erhölls som bifångster vid nätfiske utanför polska kusten mellan oktober och april åren 2006-2013 (27 av den var levande och släpptes efter mätningarna). De mått som togs var total längd på huvudet, näbbens längd från spetsen till befjädringens slut på övernäbben, näbbens höjd, tarsens längd, vingens längd och vikten. Könsbestämning skedde genom inspektion av gonaderna på de döda fåglarna. Antalet ungfåglar var få och uteslöts ur flertalet beräkningar.
Hos ungfåglarna var näbbhöjden och vinglängden betydligt mindre medan övriga mått låg inom en standarddeviation från de äldre fåglarnas medelvärde (Tabell 1). Adulta hanar hade signifikant längre huvud och näbb än adulta honor, medan övriga mått inte skilde mellan könen. Vid analysen av de senare måtten slogs därför könen ihop.

Vår sammanställning av de mått som hämtats ur litteraturen konfirmerade den ökande vinglängden och näbbhöjden från sydväst mot nordost (Figur 1). De polska tordmularna passade inte helt in $\mathrm{i}$ detta system. Näbbhöjden låg inom det 95-procentiga konfidensintervallet och passar därför i mönstret men vinglängden låg långt ovanför. Det finns en felkälla som måste beaktas när man studerar vinglängder. Trots att det uppgivits i samtliga jämförda studier att vinglängden mätts enligt principen "maximum flattened chord" kan olika personer ha mätt olika. En del av effekten kan därför vara mätfel. Men tordmularna på Gräsholm har också längre vingar än vad som är förväntat på breddgraden. Det kan därför inte uteslutas att tordmularna i Östersjön faktiskt har längre vingar än vad man haft att vänta sig utifrån regressionen i förhållande till breddgrad. 